\title{
Accessibility and Digital Media: \\ Exploring Economic and Social Opportunities for Inclusive Design
}

\author{
By \\ Natali Osadchin \\ B.Comm, Ryerson University, 2012
}

A Major Research Paper

Presented to Ryerson University

In partial fulfillment of the

Requirements for the degree of

Master of Digital Media

In the Yeates School of Graduate Studies

Toronto, Ontario, Canada, 2015

(C) Natali Osadchin, 2015 


\section{Author Declaration}

\section{AUTHOR'S DECLARATION FOR ELECTRONIC SUBMISSION OF A MRP}

I hereby declare that I am the sole author of this MRP. This is a true copy of the MRP, including any required final revisions.

I authorize Ryerson University to lend this MRP to other institutions or individuals for the purpose of scholarly research.

I further authorize Ryerson University to reproduce this MRP by photocopying or by other means, in total or in part, at the request of other institutions or individuals for the purpose of scholarly research.

I understand that my MRP may be made electronically available to the public.

\section{Signed}

Natali Osadchin 


\begin{abstract}
The following paper explores the digital media market from an accessibility point of view; what does digital accessibility look like today? What further efforts are needed to ensure digital media products and services are in compliance with universal design practices? The paper will be supplemented by both academic research, as well as ethnographic accounts of the author's experiences whilst working on AccessNow, a web service aimed at lifting mobility barriers. Topics explored include the disenfranchisement of people with disabilities in consumerist society, the dichotomy of the medical and social models, as well as a brief overview of universal web design, accessible gaming, and existing assistive technologies. Findings show there has been significant progress towards the incorporation of accessibility design guidelines, however, the process is slow and adopted by few. There is a significant gap in the accessible digital media market, which may be an enticing opportunity for economic investment.
\end{abstract}




\section{Table of Contents}

AUTHOR DECLARATION

ABSTRACT III

TABLE OF CONTENTS IV

LIST OF FIGURES $\quad$ V

1.0 INTRODUCTION

2.0 AN OVERVIEW OF THE History OF DisABILITY 2

3.0 The Dichotomy of The Social AND Medical Models 4

3.1 The Medical Model 4

3.2 The Social Model 5

4.0 The Disenfranchisement of PeOPle With Disabilities In CONSUMERIST Society 6

5.0 CURRENT PoliticAl LANDSCAPE OF ACCESSIBILITY LEGISLATION 8

5.1 THE ADA 9

5.2 THE AODA 10

5.3 ACCESSIBILITy LegisLation Around the World 11

5.4 THE ONTARIO ACCESSIBILITY INNOVATION SHOWCASE 12

6.0 An Overview of Accessible Digital Media Products and Services 16

6.1 Universal Web DESIGN 16

6.2 Assistive TeCHNOLOGIES Market 18

6.3 ACCESSIBLE GAMING 21

7.0 LinKS BETWEEN ONLINE PARTICIPATION AND WELLNESS 23

8.0 GAPS IN RESEARCH 26

9.0 ETHNOGRAPHIC ACCOUNT OF HALIFAX, NS EXPERIENCE 28

10.0 DISCUSSION 33

11.0 CONCLUSION

REFERENCE LIST $\quad 40$ 


\section{List of Figures}

Figure 1.0 - Computer and Internet Usage by Age and Disability Status..................25

Figure 2.0 - Employment Income for Adults with and without Disabilities........36 


\subsection{Introduction}

With the introduction of the World Wide Web and continued integration of digital media products and services into our daily lives, one might intuitively derive that as a globalized community physical spaces are becoming smaller, while social barriers are being disembodied in the digital space. This notion is entirely defunct when examining statistical data related to the online participation and digital media consumption of groups of individuals with disabilities (Ellis \& Kent, 2011). While there is strong evidence supporting the inclusion of people with disabilities within the digital space, which would be further explored in the paper, this segment of the market continues to be ignored, both by governmental agencies and large corporations responsible for the production and selling of digital media products and services. The following paper will examine such gaps in the market, utilizing existing academic research and data, infused with ethnographic accounts of my experiences while working on AccessNow, a digital service targeted at people with physical impairments.

AccessNow is a web-based service that utilizes crowdsourcing to pinpoint accessibility information on an interactive map. A fellow colleague founded this venture, and I felt inspired and compelled to come on board, to try and help in any way possible. The past few months of working on the project have been a whirlwind of events and learned experiences. As a disclaimer, I am an ambulatory individual, with no other disabilities or impairments. My understanding of disability is therefore based off of second-hand experiences, which ultimately shaped the construction of this paper. I in no way consider myself an activist, but rather as a bystander, in a society filled with good intentions, yet lacking the tools and understanding to implement positive change. 
This paper will be focused on individuals with physical, learning, mental, and/or developmental disabilities, exploring digital accessibility as an overarching term. Key topics and definitions include a historical account of the origin of the term 'disability'; the difference and historical application of the medical and social models in relation to disability; the exclusion of individuals with disabilities from economic market activities; the present-day political landscape of accessibility legislation; and existing accessible digital media products and services. The ethnographic accounts of my experience working on AccessNow will be peppered in throughout these sections, to help demonstrate a real-life application of abovementioned concepts and theories.

\subsection{An Overview of the History of Disability}

Disability in and of itself is a plastic term, influenced heavily by changing currents in society, specifically relating to ethnic, race and class divisions (Connor \& Ferri, 2013). The notion of disability and the classification of individuals based on their abilities and race can be traced back to a post industrial revolution world, when the concept of 'normalcy' was first constructed (Davis, 2013). The emergence of the statistics field, used first in the 19th century as a way to gain an insight into growing urban populations, led to the development of the 'average man', or the 'ideal citizen' (Davis, 2013; Connor \& Ferri, 2013). The concept of ‘ideal citizen' was ingrained in North-American society as an able-bodied, white male, and anyone who fell outside this definition was considered a second-class citizen at best, and an outcast at worst (Connor $\&$ Ferri, 2013). One example of said divisions came in the form of the 1882 Undesirables Act, enacted in the US, which encouraged immigration authorities to conduct medical 
tests and examine incoming immigrants based on a set of exclusionary criteria (Connor \& Ferri, 2013). Notably, immigrants were sent away if deemed 'unfit' to become citizens, specifically referring to an individual's ability to take care of himself or herself (Connor \& Ferri, 2013). Legislative measures such as the 1882 Undesirables Act, combined with the ever-growing popularity of eugenics, contributed to the systematic intolerance of people with disabilities (Connor \& Ferri, 2013).

Discrimination of people with disabilities was brought to public attention in the 1970s, alongside the rise of other civil rights movements, some of which included African-Americans, women, and homosexuals (Connor \& Ferri, 2013). In light of the call for action and equality for all individuals in the US, the following decades brought forth such legislation as the Individuals with Disabilities Education Act (IDEA) and the American with Disabilities Act, passed in 1990 (Connor \& Ferri, 2013). There currently is not one overarching disability related legislation on the federal level in Canada, a responsibility which thus far has been left to the individual provinces, including the province of Ontario which enacted the Accessibility for Ontarians with Disabilities Act (AODA) in 2005 (McColl et al., 2010). While westernized nations were beginning to tackle the issue of disabilities in the latter part of the twentieth century, the debt crises of the same era were preventing many other countries from paying attention to disability issues on their own turf (Davidson, 2006). Ongoing globalization contributed heavily to the debt crises of the 1970-80s, forcing nations to forego social assistance programming in favour of making interest payments to debtor nations (Davidson, 2006). 


\subsection{The Dichotomy of the Social and Medical Models}

In the discussion of disability studies two conceptual models are discussed; the social model and the medical model. Both frameworks have been instrumental in the formation of the term 'disability' as is understood today. The medical model, the prevalent school of thought until more recent history, defines disability within the confines of one's impairment (Hoppestad, 2007; Rothman, 2010; Easton, 2013;

Gallagher, Connor, \& Ferri, 2014; Goering, 2015). According to the medical model any disadvantages experienced by an individual are due to an existing physical, developmental or learning impairment, which can only be remedied through medical treatment (Goering, 2015). The social model, a more recently adopted framework, argues disabilities are created through societal constructions (Rothman, 2010; Easton, 2013; Gallagher, Connor, \& Ferri, 2014; Goering, 2015). The accessibility of the physical environment, stereotypes, constructs of 'normalcy' and employment discrimination are only a few examples of ways in which disability manifests itself, within the context of the social model (Rothman, 2010). In short, while the medical model focuses on the individual's control over change and effort, the social model puts the focus on existing social institutions and the necessary changes in ways of thinking (Rothman, 2010).

\subsection{The Medical Model}

The medical model is rooted in two prominent ideologies; first is the moral model, whereas disability is viewed as a punishment for sin, and society has the moral obligation to care for such individuals (Rothman, 2010). Second is social Darwinism, or the survival of the fittest - if medicine cannot 'cure' the disability, these individuals must 
be removed from society (Rothman, 2010). Critics of the medical model argue that people with disabilities rely on the expertise of medical professionals who are in control of access to support services (Rothman, 2010; Easton, 2013). This creates a sense of dependency in individuals with a disability, while simultaneously isolating said individuals from 'normal' societal activities (Rothman, 2010; Goering, 2015). Though fewer in number, there is some hesitation in solely relying on the social model when discussing disability. According to some scholars the social model treats disability as an overly simplified range, whereby physical, developmental and learning disabilities are grouped together (Gallagher, Connor, \& Ferri, 2014). They also warn against treating disability solely within the social oppression context, as it may alienate individuals with disabilities from medical professionals, who could help said individuals increase functioning in a significant way (Anastasiou \& Kauffman, 2013; Gallagher, Connor, \& Ferri, 2014). These criticisms have provided for meaningful dialogues on the implications of using either models, therefore calling for a more balanced approach.

\subsection{The Social Model}

The adoption of the social model had led to an important distinction between impairment and disability (Anastasiou \& Kauffman, 2013; Gallagher, Connor, \& Ferri, 2014; Goering, 2015). Impairment is defined as a physical, developmental, or sensory functional limitation, whereas disability is defined as the loss or limitation of opportunities due to social constraints (Anastasiou \& Kauffman, 2013; Goering, 2015). Impairment refers to flawed bodily function, while disability is expounded in relation to 
social organization (Anastasiou \& Kauffman, 2013). The use of the medical model can subsequently create additional disability, by disallowing individuals to feel good about themselves, when surrounded with daily subverting messages from the non-disabled population (Goering, 2015). People with impairments may be of minority, however that does not preclude them from participating in society to a full extent, so long as an inclusive framework is available (Goering, 2015).

\subsection{The Disenfranchisement of People with Disabilities in Consumerist Society}

The guiding principles of capitalism dictate that the individual is empowered through choice; more specifically, the choice to allocate resources as deemed appropriate (McClimens \& Hyde, 2012). The industrial revolution allowed capitalist societies to take advantage of mass-production on a large-scale, standardizing operations to lower production costs, in an attempt to feed society's newfound thirst for consumption (Migone, 2007). Production standardization and the strive for economies of scale, have forced enterprises to offer a limited selection of products, aimed to satisfy the largest market segments, thereby ignoring minority groups (McClimens \& Hyde, 2012; Migone, 2007). In an industrial society, whose economy is driven by employment and production, those who are not able to participate and contribute are looked down upon, and often cast aside (McClimens \& Hyde, 2012). Consumerism has a large role in defining one's self worth, and continues to be a significant prerequisite in participation in contemporary life (McClimens \& Hyde, 2012). Disallowing the participation of certain groups, such as people with disabilities, from the consumption process can be said to have significant ramifications on the social well being of said outcast groups (McClimens \& Hyde, 2012). 
A form of consumerism, coined as 'political consumerism', is aimed at changing institutional and market practices through the power of buying decision-making (Micheletti \& Stolle, 2008). Consumers are encouraged to make ethical and informed purchasing decisions, in an attempt to put pressure on large corporations to change existing practices (Micheletti \& Stolle, 2008). Individuals are beginning to move away from hedonistic consumerism, defined as consumption rooted in the purpose of bringing joy and bliss, to ethics-driven consumerism, aimed at bringing attention to social justice matters (Migone, 2007; Micheletti \& Stolle, 2008). People with disabilities have been excluded entirely from consumerist culture over the past couple of centuries, both by being unable to contribute to production, as well as by mass-production practices, which by definition do not cater to the marginalized groups within capitalist society. The shift towards political consumerism and the continuous search for new revenue-generating ventures, will aid in putting pressure on corporations to consider accessibility in their design practices.

Through the experience of working on AccessNow I have learned that there is very little use in waiting for others to implement change. As a consumerist society we are used to having our needs and wants dictated to us. First, we had to let go of the idea that 'someone will make this' and 'it must already exist'. Upon initial investigation we indeed discovered there are a few players in the field, however we felt the services they offered did not hit all the marks we set out. In fact, we treated the existing competitors as an affirmation of the idea and need for an accessibility-focused map, and decided to go ahead and attempt to build our vision. Whether it is waiting for someone to offer their web development skills, or waiting on governmental bodies to provide an elusive database of accessibility information, we had to change our approach to building 
AccessNow. The idea shifted from simply providing information to the end-user, to harnessing the power of crowdsourcing to help populate the most current and up-to-date accessibility data. Next, we pivoted the concept to be web-based, as opposed to a native mobile application, mostly due to budgetary and timing constraints. Although we recognize native mobile applications would operate better than web-based applications in conjunction with various assistive technologies, we simply could not afford to go down that route. It is a problem that many organizations and corporations continue to face as they evaluate accessible design options, potentially leading to the continued disenfranchisement of people with disabilities from consumerist society.

\subsection{Current Political Landscape of Accessibility Legislation}

2015 marks a celebratory anniversary for two important accessibility legislations; the Americans with Disabilities Act (ADA) which came into effect in 1990, as well as the tenth anniversary of the Accessibility for Ontarians with Disabilities Act (AODA) (Rush, 2012; Ross, 2013; Flaherty \& Roussy, 2014). The joint milestone anniversary in combination with the Pan-American and Para Pan-American games, which took place in Toronto this summer, have put accessibility at the forefront of discussion. While both social legislations are recognized as momentous within their own regard, different criticisms point to the flaws of said acts (Cox, 2012; Ross, 2013; Flaherty \& Roussy, 2014). The criticisms are primarily focused on the vague language, lack of conformance with legislation, and the use of the medical model as a way to define who falls under the definition of 'disability’ (Cox, 2012; Ross, 2013; Flaherty \& Roussy, 2014). 


\subsection{The Americans with Disabilities Act}

Following the civil rights movement in 1960s U.S., several legislations were enacted to help protect the rights of racial minorities, women, and gay and lesbian individuals, to name a few (Karger \& Rose, 2010). One minority group was notably missing from any mentioning in those legislations, that of people with disabilities, leading to the eventual enactment of the ADA in 1990 (Karger \& Rose, 2010). The ADA consists of five main titles; employment, public services, public accommodations, telecommunications services, and miscellaneous provisions, respectively (Karger \& Rose, 2010; Rush, 2012). The ADA is enforced through specialized federal agencies, and though generally considered vigorous in nature, it allows for some flexibility, specifically within the parameters of the first and second titles (Karger \& Rose, 2010).

A recurring criticism of the ADA is in relation to the definition of 'disability' and the criterion upon which individuals are assessed on whether they qualify for protection under the ADA (Cox, 2012; Rush, 2012). An amendment to the ADA came in 2008 as a response to the courts' focus on the medical model, and thus the definition of 'disability' as a physical or mental impairment (Cox, 2012). The amendment included more explicit terms for ADA beneficiary qualifications; these include relaxation of the severity threshold for ADA beneficiaries, elimination of durational requirements for ADA coverage, and the coverage of work limitations such as pregnancy (Cox, 2012; Rush, 2012). Recent census data shows that the ADA has not been successful in making a dramatic improvement to the economic well being and overall quality of life for those individuals living with a disability (Karger \& Rose, 2010). Some individuals self report a degree of improvement to their lives following the enactment of the ADA, however 
employment rates continue to be drastically lower than of people without a disability (Karger \& Rose, 2010).

\subsection{The Accessibility for Ontarians with Disabilities Act}

The AODA was enacted in 2005, alongside a promise to make Ontario fully accessible by 2025 (Ross, 2013). The AODA was built upon its predecessor, the Ontarians with Disabilities Act (ODA), passed in 2001 (Flaherty \& Roussy, 2014). Ontario was the first jurisdiction within Canada to implement accessibility standards for public and private organizations and spaces alike (Flaherty \& Roussy, 2014). The AODA, though a social legislature by nature, defines 'disability' as a bodily impairment, in line with the medical model, and a direct replica of the definition originally found in the Human Rights Code (Ross, 2013). There is currently limited to no legal obligation for organizations to become compliant with the accessibility standards outlined in the AODA (Flaherty \& Roussy, 2014).

Widespread criticisms of the delayed implementation of accessibility standards have led to the development of various provincial agencies aimed at focusing on different aspects of accessibility for people with disabilities, including but not limited to, education, health, and employment (Ross, 2013). In a recently released independent periodical review of the AODA and its progress to date, it was established that the legislation was 'too weak' for people with disabilities and 'too confusing' for businesses and municipal governments to enforce (Monsebraaten, 2015a). A major criticism of the AODA is that there are no provisions requiring buildings to be retrofitted, in an effort to eradicate the largest problem for people with disabilities, which is building accessibility 
(Monsebraaten, 2015a). In addition, the report revealed that over $65 \%$ of businesses have failed to file their 2012 accessibility compliance reports (Monsebraaten, 2015b). Counter intuitively, the provincial government announced they would be conducting only 1,200 compliance audits in the coming year, a dramatic decrease from the 1,950 average of the previous two years (Monsebraaten, 2015b).

Accessibility advocates are skeptical of the Ontario's efforts to become fully accessible by 2025 , leading to the government's recent announcement of new accessibility measures (The Canadian Press, 2015). The newly introduced plan is focused on providing employment opportunities for people with disabilities, as well as rewarding businesses that hire and retain employees with disabilities (The Canadian Press, 2015). Other initiatives include a focus on accessibility within the health care sector, as well as the development of a third party accreditation program to recognize accessible businesses, similar to LEED (Monsebraaten, 2015b; The Canadian Press, 2015).

\subsection{Accessibility Legislation Around the World}

Research shows that as many as one fifth of the world's poor population is comprised of people with disabilities (Ahmad \& Ahmad, 2011). The World Health Organization reports that close to $80 \%$ of the disabled poor live in low-income countries, primarily in rural areas (World Health Organization, 2014). Access to public services is limited and often denied, and while there have been international efforts to create public policies pertaining to disability and accessibility in low-income regions, namely SouthEast Asia, there is little to no evidence of successful implementation (Ahmad \& Ahmad, 2011). Research shows that some of the reasons these initiatives have failed to improve 
the lives of the disabled poor in the specified regions include a vague definition of the needs of the disabled poor, as well as the misconceptions that the disabled poor operate with low efficiency (Ahmad \& Ahmad, 2011). Continued advocacy for the rights of individuals with disabilities, as well as both national and international monitoring of compliance with enacted legislation, are imperative in the road for greater accessibility and inclusive design in low-income regions.

The former European Community (EC) launched a disability strategy aimed at identifying and removing barriers preventing individuals with disabilities from fully participating in social life (Ferri, \& Giannoumis, 2014). This initiative acted as the cornerstone for later accessibility legislations, specifically the European Union (EU) Disability Action Plan (2004-2010) and its successor, the European Disability Strategy (2010-2020), the current policy in place (Ferri, \& Giannoumis, 2014; Priestley \& Lawson, 2015). Synchronically, the United Nations (UN) Convention on the Rights of Persons with Disabilities came into force in 2008, outlining 50 articles focused on various accessibility related issues (Priestley \& Lawson, 2015). The EU Disability Strategy was designed to work in accordance with the UN conventions (Ferri, \& Giannoumis, 2014; Priestley \& Lawson, 2015). The EU has yet to establish European Accessibility Legislation, originally promised to come into effect in 2012, and while the disability strategy has valid content, it lacks actionable goals (Plura, 2014).

\subsection{The Ontario Accessibility Innovation Showcase}

In preparation for the Para Pan-American games that took place in Toronto, $\mathrm{ON}$ during the summer of 2015, the Ontario government launched an initiative called the 
Ontario Accessibility Innovation Showcase (AIS). This showcase took place over the opening weekend for the Para Pan-Am games, as a way to raise awareness of accessibility issues and highlight innovative technologies and ventures that are working towards solving the problem of inaccessibility. My partner and I decided to apply as an exhibitor in the showcase, hoping to capitalize on the opportunity by using the AIS as a Launchpad for our soon-to-be completed website, AccessNow.

The details of the showcase were not finalized until what seemed like the last minute. The application documents and all communication were outdated with long passed dates, a testament to the hurried nature of the entire event. We quickly learned that we have been accepted as exhibitors, as well as will have the chance to compete in a pitch competition for a significant sum of money. We were ecstatic at the prospect of the opportunity, and began working on the completion of the website, as well as the design of various promotional materials and literature.

The day quickly rolled around, and we found ourselves at the opening ceremony for the AIS, on a very quiet Saturday morning in downtown Toronto. Inside the building, however, there were many people milling around; exhibitors, volunteers, media personnel, and various political figures. While waiting for a morning coffee, Ontario's premier walked through the crowd, stopping briefly to shake hands with my partner and I, smiling widely for the cameras surrounding us. Moments later all attendees were called to the main stage area for an official ribbon cutting ceremony.

In the next hour, many important political figures took their turn on stage and spoke of the great advancements in accessibility technology, while also mentioning the 
wonderful progress achieved through the ADA and AODA legislations, both celebrating a milestone anniversary. The speeches were all very similar in context, and all but one, failed to acknowledge the pitfalls of said legislations and the work that is still ahead. Nonetheless, it was empowering to be in the company of persons of such high influence, and we could not wait any longer to show the world the project we have been working on tirelessly. The excited crowd was quickly dismantled, and it was time for the showcase to begin.

We headed towards the designated area, where we have set up our materials the previous day, to find out our things have been moved from their original corner spot. Our materials were originally set-up at the corner of a long shared table, to make it more accessible for my partner who uses a power chair. We thought, "this must be a mistake", and went to our organizer to sort matters out. Surprisingly we were met with more resistance than we perhaps anticipated. The exhibitors were reluctant to give up their newly claimed space, trying to convince us to use a tall cocktail table from a nearby food court, "this will be easier for demoing". Though we were caught off guard we shot back, "not if the person is in a wheelchair - the table is far too tall!". It was disheartening to realize that there were exhibitors at an accessibility showcase that had very little understanding of the needs of people with disabilities.

A couple of hours later we found a vacant table in the main reception area, and asked to be set up there. Once settled, we realized the sheer emptiness of the space; there were barely any visitors. A space that seemed almost uncomfortably busy only a few hours earlier, was entirely without any visitors. Speaking to some of the event organizers revealed that attendance was in fact much lower than initially anticipated. Reasons for 
the low numbers could be a combination of any of the following; it was a summer weekend, meaning many people were enjoying outdoor activities and were perhaps out of town; the showcase took place in a business building with little residential living and/or tourist attractions nearby; and finally the showcase seemed to have been put together in a rush, with very minimal advertising and promotion.

Despite the initial hiccups, our new location attracted many visitors to our booth, who enthusiastically listened as we walked them through a demonstration of our site. We heard lots of encouraging and positive feedback, however even more valuable were the suggestions on how we can improve the service, delivering a better end-user experience. These suggestions were a testament to a possibility of building a community around accessibility issues, which is exactly what we aim to create with AccessNow. We believe it is through the collaborative efforts of community that we can firstly, cover the world's map with accessibility information and secondly, spark a conversation on how we can turn inaccessible spaces into accessible ones. The driving force behind the crowdsourced model is that no one knows accessibility information better than the people who need it on a regular basis.

Overall, the Ontario AIS was a valuable experience both in terms of exposure and customer feedback. We received national news coverage from several networks and news stations, with appearances on TV, radio, as well as online and printed newspapers. In addition, we met with many potential partners, ranging from fellow start-up entrepreneurs with similar ventures, to local government tourism agencies. Our website visitation numbers spiked, and we are now working vigorously on retaining the same level of interest in the coming months. There has been no communication since the end 
of the showcase on whether this event will be repeated in the future. The skeptic in me finds it hard not to view this event as a photo opportunity for the politicians that came on the first morning of the showcase. The Pan-American and Para Pan-American games have been instrumental in the conversation on accessibility in Toronto and other regions alike. Hopefully it is not a matter of momentum but rather the start of meaningful and indepth analysis of the current state of affairs.

\subsection{An Overview of Accessible Digital Media Products and Services}

\subsection{Universal Web Design}

An effort to standardize web accessibility design, was first introduced in 1995, outlining strategies for existing and future HTML-based web page design (Vanderheiden, 1995). Other contributions followed in the next few years, eventually leading to the development of the Web Content Accessibility Guidelines (WCAG), developed by the Web Accessibility Initiative (WAI), and first published by the World Wide Web Consortium (W3C) in 1999 (Kelly et al., 2005; Kelly et al., 2009a). The WAI believes that conformance with the WCAG in combination with two other sets of guidelines the organization had set out, User Agent Accessibility Guidelines (UAAG) and the Authoring Tools Accessibility Guidelines (ATAG), will lead to universal web accessibility (Kelly et al., 2005). While the WCAG are considered by many as the main approach to universal design, web accessibility levels are still dissatisfying (Kelly et al., 2005; Ribera et al., 2009; Easton, 2011; Hanson \& Richards, 2013). 
Critics argue that there are several limitations to the WCAG, some of which include an unrealistic implementation approach which does not consider the diverse uses of the Web technologies and web developers' inability to control the development of Web authoring tools (Kelly et al., 2005). A revised version, titled WCAG 2.0, was released in 2008 to address some of the limitations put forward (Ribera et al., 2009; Kelly et al., 2009a). WCAG 2.0 is designed to address the ever-changing landscape of the web design and development fields, providing a more educational framework (Ribera et al., 2009). The updated set of guidelines allows the user more control of the interface, as well as addresses a wider variety of disabilities in its recommendations (Ribera et al., 2009).

Several policy makers have adopted the WCAG, with the US being the first to incorporate the guidelines into their legislation as part of the Americans with Disabilities Act (Ribera et al., 2009).

A recent study explored the efficacy of the WCAG, comparing over 100 top traffic and governmental sites over a 14-year period (Hanson \& Richards, 2013). Notably governmental sites had a higher compliance rate with the WCAG, when compared to other top-traffic sites, in some areas but not all (Hanson \& Richards, 2013). There is little evidence as to whether the increased compliance rates resulted from the introduction of the WCAG or were simply a derivative of improved web page design and prominence through good coding practices (Hanson \& Richards, 2013). In addition, research shows that larger corporations have a higher rate of web accessibility compliance when compared to smaller enterprises (Loiacono \& Djamasbi, 2013). Some factors may include a larger IT department, level of accessibility testing, and whether accessibility guidelines have been incorporated into design policies (Loiacono \& 
Djamasbi, 2013). It can therefore be derived that organizations that choose to incorporate accessibility guidelines in their website design, are able to do so due to increased access to both human and capital resources.

\subsection{Assistive Technologies Market}

Assistive technologies have a profound impact on various individuals' ability to live independently (Abbott, 2007; Hakobyan et al., 2013; Zhuang et al., 2013). These technologies range from screen readers for the visually impaired, to voice-over capabilities on mobile devices (Hakobyan et al., 2013; Cumming et al., 2014). The continuous development of various mobile platforms had been a challenge in the assistive technologies market (Zhuang et al., 2013). While native mobile applications offer the best capabilities, it requires separate codes for each platform, an expensive and inefficient process (Zhuang et al., 2013). Mobile web pages offer a universal mechanism that works on all modern mobile platforms, however it is much slower and inefficient when compared to native applications (Zhuang et al., 2013). A recent research study explores the costs and challenges associated with developing assistive technologies that run on multiple mobile platforms, and the idea of 'one-size-fits-all' (Hakobyan et al., 2013; Zhuang et al., 2013). The research suggests that it is difficult to implement a 'onesize-fits-all' solution, and it does not truly exist in the current market (Zhuang et al., 2013). Native application development requires vast resources, in the form of knowledge and/or capital, as every platform's API is drastically different, while web applications are simply not fast or efficient enough for deployment on modern mobile devices (Zhuang et al., 2013). 
During the developmental stages of AccessNow, we had to come to a decision pertaining to what platform we will use as the building blocks of our service. While we understood the benefits of a native mobile application, namely efficiency and overall improved usage experience, there were still elements that held us back. We contacted several mobile application development firms in Toronto, from boutique to large international enterprises, and received quotes for the project in the $\$ 30,000 \mathrm{CND}$ range. In most cases this price tag would provide us with a dedicated team, including a web developer and UI designer. We quickly abandoned the idea of a native application due to its incredibly high costs, and our inability to maintain the back-end operations in the long-term, due to lack of technological domain knowledge within the team. We have tried to recruit some of the firms we spoke to, as a pro-bono project, however everyone politely declined. This process had led to a significant pivot in our business plan, which is now based on the development of a mobile-friendly Wordpress website. Although using a web application limits our ability to customize the website, both in terms of layout as well as accessibility features, we feel it is the best course of action at this point. We view this decision as a starting point that will help get us where we need to be in the future.

A recent study explored mobile technology usage habits by individuals with intellectual disabilities in a research capacity, in an attempt to understand the impact the use of mobile devices has on the lives of said individuals (Cumming et al., 2014). The tablets used in the study were chosen as inexpensive and easily customizable tools, while also having unobtrusive qualities (Cumming et al., 2014). The tablets were deemed a helpful research tool, while also providing the study participants social opportunities in the form of connection with support workers and other community members 
(Schaffhauser, 2013; Cumming et al., 2014). The study concludes that as mobile technologies continue to become more ubiquitous, from transit navigation to cooking instructions, individuals with intellectual disabilities will require training and support on how to use said technologies (Hakobyan et al., 2013; Cumming et al., 2014). A positive element of mobile assistive mobile technologies is that generic devices can be easily customized to the needs of an individual through the download of applications, and simple modification of the settings (Schaffhauser, 2013). Mobile technologies can quickly cross the line from a helpful resource to a barrier in social participation (Cumming et al., 2014).

Ease of use and accessible features are two elements that have been on the forefront of our minds as we continue to work on AccessNow. We recognize that while we want to get the product out to market as swiftly as possible, we are also very conscientious of our target market, namely individuals with physical impairments. It is important to us that the process of adding accessibility information to the map, that the process is as intuitive and smooth as possible. We may not be able to cater to all groups of individuals with disabilities, due to limited technical and capital resources, but we hope to continue evolving the universality of the application in the near future. After speaking to our target demographic as well as specialists in the accessible technologies industry, we were able to narrow down our design priorities for the first stage of development. 


\subsection{Accessible Gaming}

Over the past 40 years, online gaming has evolved from a two-person interaction in close proximity, to endless 3D virtual worlds played by millions of people worldwide (Freddolino \& Blaschke, 2008; Carr, 2010; Crawford, Gosling \& Light, 2011). Online games have now surpassed movie ticket sales figures, and are a prevalent daily routine in many Americans' lives, with an estimated 100 million video game consoles present in US households (Freddolino \& Blaschke, 2008; Yuan, Folmer \& Harris, 2011) The rapid rise in popularity of online gaming can be attributed to several key factors, most notably including the revolution of the personal computer, followed closely by global connectedness via the Internet, and finally, the introduction of massively multiplayer online role-playing games, or MMPORGs (Freddolino \& Blaschke, 2008). Online gaming provides a social framework, where players build communities, discuss strategies and solutions, and learn about choice and consequence (Freddolino \& Blaschke, 2008). Tapping into the engagement component of online gaming, organizations have been incorporating games in the education, health, religion and politics fields as tools of information delivery and social participation (Yuan, Folmer \& Harris, 2011). As games continue to evolve beyond the entertainment value, it is becoming increasingly more critical to understand the consumption patterns of online games by people with disabilities.

An attempt to create standardized accessibility game design guidelines, similar to the WCAG, was published in 2004, however the guidelines were deemed limited in scope, as they applied to a small selection of game genres, and assumed total validity (Yuan, Folmer \& Harris, 2011; Garber, 2013). Research suggests that creating a number 
of design guidelines, in an effort to combat generalizability and validity, are necessary in accessible game design (Freddolino \& Blaschke, 2008). Similar to inclusive web design and the WCAG, governmental legislation may help speed the process of accessible game design guidelines (Garber, 2013). Beyond the economic incentive of potential increase in sales, governments may incorporate an incentive-based program, similar to environmental economic incentives used in the past.

There are two approaches to incorporating accessible features in game design; modify an existing game, or create a game aimed at accommodating a particular disability (Yuan, Folmer \& Harris, 2011). Game developers may be deterred from using either approaches, as incorporating accessibility features into an existing game can significantly alter the playing experience, while building an accessible game from scratch may be deemed too costly (Yuan, Folmer \& Harris, 2011; Garber, 2013). Recent research suggests that $63 \%$ of the US population play video games, and an estimated $51 \%$ of that figure play games on a weekly basis (Yuan, Folmer \& Harris, 2011). At the same time, two percent of the US population cannot play games at all, while nine percent can play at a reduced level, due to a disability, accounting for about 35 million people in the US alone (Garber, 2013). A rough projection would therefore suggest that there are 22 million people with a disability in the US that are largely ignored by game developers. A staggering number when thought of in terms of revenue dollars, making the disabled population a lucrative, and for the most part untapped market segment, for video game development. 


\subsection{Links between Online Participation and Overall Wellness}

Much literature exists on the topic of online participation and its effect on overall well being, which may refer to the social, health or financial areas of one's life. There are numerous opinions on the spectrum of positive to negative influences, and while the author recognizes all as valid, the following section will primarily focus on the positive impact of online participation on an individual's well being. The emergence of Web 2.0 in recent years had led to a revolution in online content generation practices; the endusers are both consumers and producers of online content (Song, 2010). This may manifest itself in the form of video and written blogs, social network sites (SNSs), as

well as crowd sourced information platforms such as Wikipedia (Song, 2010; Tzavela \& Mavromati, 2013). Recent data shows that $75 \%$ of worldwide Internet users visit a SNS or blog when they connect online (Tzavela \& Mavromati, 2013). Social interaction, while not necessarily replacing traditional socialization, is increasingly taking place in the online forum (Song, 2010). Contrary to popular belief that the web allows the disembodiment of individuals, research shows that the online space allows individuals with disabilities to discuss their impairments, and therefore increase web affordances (Bundon \& Clarke, 2015). The emergence and popularization of SNSs and online support groups have provided individuals with disabilities a space where they can connect with others who may face similar impairments (Miller, 2008; Blom et al., 2014; Shpigelman \& Gill, 2014; Bundon \& Clarke, 2015). This leads to the development of meaningful relationships and friendships that perhaps would not have been readily available in the non-virtual world (Miller, 2008; Blom et al., 2014; Shpigelman \& Gill, 2014; Bundon \& Clarke, 2015). 
Putnam defines 'social capital' as the elements that allow individuals to unite for the common good, and improved health, through increased access to material and symbolic resources (Koutsogeorgou et al., 2014; Bundon \& Clarke, 2015). This may be exemplified in social networks, norms in trust, where groups with high social capital tend to exhibit overall improved health, when compared to more individualistic groups (Koutsogeorgou et al., 2014). The same principles can be applied to online interaction, with the emergence of web 2.0, and the emphasis on globalized online communities. Online participation is becoming more ubiquitous, thus rising in importance in its contribution to one's social capital. People with disabilities who benefit from online interaction are therefore able to increase individual as well as collective social capital (Bundon \& Clarke). As mentioned before, increased social capital can lead to overall improved health and social well-being, leading to the conclusion that online participation in individuals with disabilities has overall positive effects (Miller, 2008; Blom et al., 2014; Shpigelman \& Gill, 2014; Bundon \& Clarke, 2015).

According to recent U.S. Census data found in Figure 1.0 below, people with severe disabilities have significantly lower Internet and computer usage rates when compared to people with non-severe disabilities, and even lower when tracked against usage rates of people without disabilities (U.S. Census Bureau, 2010). These figures plummet to minimal to no use when examining the population of people with disabilities over the age of 65 , comparable to usage rates of seniors without disabilities (U.S. Census Bureau, 2010). As seen in Figure 1.0 below, people with severe disabilities display significantly lower Internet and computer usage rates in a work and/or school environment, for the 15-64 age group (U.S. Census Bureau, 2010). Some contributing factors may include lower employment and school enrollment rates, for people with 
severe disabilities, which may result from the inaccessible nature of many workplaces and educational institutions (Karger \& Rose, 2010). Further research is necessary to better understand the reasons for the low Internet and computer usage rates amongst the senior population. As computers continue to become more ubiquitous it is imperative that the senior population is equipped with the right tools and equipment to be able to participate in modern social life. Internet usage has been said to have positive affects on seniors' lives by lessening loneliness, boredom, helplessness, and the decline of mental capacity (Sum et al., 2008). Research suggests that learning to use a computer can increase self-confidence, the desire and ability to learn, as well as help with memory retention in senior persons (Sum et al., 2008).

\section{Figure 1.0}

Computer and Internet Usage by Age and Disability Status: 2010 (Numbers in thousands)

\begin{tabular}{|c|c|c|c|c|c|c|c|c|}
\hline \multirow{2}{*}{$\begin{array}{c}\text { Disability and } \\
\text { Computer/Internet Usage }\end{array}$} & \multicolumn{4}{|c|}{15 to 64 years } & \multicolumn{4}{|c|}{65 years and older } \\
\hline & Number & $\begin{array}{l}\text { Margin of } \\
\text { Error }( \pm)^{1}\end{array}$ & Percent & $\begin{array}{l}\text { Margin of } \\
\text { Error }( \pm)^{1}\end{array}$ & Number & $\begin{array}{l}\text { Margin of } \\
\text { Error }( \pm)^{1}\end{array}$ & Percent & $\begin{array}{l}\text { Margin of } \\
\text { Error }( \pm)^{1}\end{array}$ \\
\hline No disability & 170,863 & 783 & 100.0 & $(X)$ & 19,365 & 327 & 100.0 & $(\mathrm{X})$ \\
\hline Uses a computer at home & 129,643 & 1,027 & 75.9 & 0.5 & 10,112 & 323 & 52.2 & 1.4 \\
\hline Uses a computer at school/work & 97,751 & 1,031 & 57.2 & 0.5 & 2,762 & 171 & 14.3 & 0.9 \\
\hline Uses the Internet at home & 104,700 & 1,173 & 61.3 & 0.6 & 7,600 & 290 & 39.2 & 1.4 \\
\hline Uses the Internet at school/work & 74,899 & 991 & 43.8 & 0.6 & 1,851 & 147 & 9.6 & 0.8 \\
\hline Uses the Internet at other place & 34,291 & 834 & 20.1 & 0.5 & 1,381 & 124 & 7.1 & 0.6 \\
\hline Nonsevere Disability & 10,674 & 419 & 100.0 & $(X)$ & 5,096 & 221 & 100.0 & $(\mathrm{X})$ \\
\hline Uses a computer at home & 7,482 & 318 & 70.1 & 1.7 & 2,038 & 135 & 40.0 & 2.1 \\
\hline Uses a computer at school/work & 5,401 & 264 & 50.6 & 1.8 & 380 & 67 & 7.5 & 1.3 \\
\hline Uses the Internet at home & 6,275 & 311 & 58.8 & 1.8 & 1,490 & 118 & 29.2 & 2.0 \\
\hline Uses the Internet at school/work & 4,174 & 225 & 39.1 & 1.6 & 240 & 50 & 4.7 & 0.9 \\
\hline Uses the Internet at other place & 2,626 & 188 & 24.6 & 1.4 & 318 & 61 & 6.2 & 1.2 \\
\hline Severe disability & 21,545 & 606 & 100.0 & $(X)$ & 14,138 & 276 & 100.0 & $(\mathrm{X})$ \\
\hline Uses a computer at home & 11,515 & 438 & 53.4 & 1.0 & 3,641 & 175 & 25.8 & 1.1 \\
\hline Uses a computer at school/work & 4,470 & 241 & 20.7 & 0.9 & 397 & 60 & 2.8 & 0.4 \\
\hline Uses the Internet at home & 8,699 & 386 & 40.4 & 1.1 & 2,425 & 159 & 17.1 & 1.1 \\
\hline Uses the Internet at school/work & 3,071 & 194 & 14.3 & 0.8 & 229 & 47 & 1.6 & 0.3 \\
\hline Uses the Internet at other place & 3,034 & 215 & 14.1 & 0.9 & 397 & 68 & 2.8 & 0.5 \\
\hline
\end{tabular}

Source: U.S. Census Bureau, Survey of Income and Program Participation, 2008 Panel, Wave 6 Topical Module, May-August 2010.

Notably, certain groups with disabilities were reported to have significantly lower online participation rates, when compared to others (Miller, 2008; Shpigelman \& Gill, 
2014). In a specific study exploring SNS usage patterns by adults with intellectual disabilities, it was revealed that they visit Facebook once a week, compared to the public average of once a day, at minimum (Shpigelman \& Gill, 2014). The researchers concluded that the reason for the stark difference in usage rates was not due to the 'digital divide', or restricted access to technology based on demographics, but rather due to the reading and comprehension skills required to use the SNSs (Shpigelman \& Gill, 2014). Online transactions continue to replace traditional forms of exchange, epitomized as information search, shopping, and banking, to name a few, becoming an integral part of daily life (Mahmud \& Ramakrishnan, 2012). This poses a difficulty for people not possessing appropriate reading and comprehension skills, or those who rely on assistive technologies to disseminate information (Mahmud \& Ramakrishnan, 2012; Shpigelman $\&$ Gill, 2014). The integration of accessible web design into the development of social, user-generated content websites can have a profound effect on the quality of life of those individuals living with a disability.

\subsection{Gaps in Research}

There is little evidence pertaining to the relationship between governmental intervention and web accessibility compliance rates. While research shows that on average government sites incorporate accessibility guidelines at a higher rate than other top traffic sites (Hanson \& Richards, 2013), it fails to address whether legislation would have a positive impact on the incorporation of accessibility guidelines in web design. It should also be noted that research is focused primarily on top traffic sites originating in English-speaking countries with enacted web accessibility policies (Hanson \& Richards, 2013). Findings should not be applied universally as they do not address the market 
landscape in non-English speaking countries, which do not currently have enacted legislation focused on web accessibility issues.

The study exploring the efficacy of use of mobile technologies in individuals with intellectual disabilities is limited in scope, as it touches on a very limited sample of the general population, specifically female researchers with intellectual disabilities (Cumming et al., 2014). Similarly the study investigating Facebook usage rates amongst adults with intellectual disabilities is restricted both due to the limited sample examined, as well as the website examined, as SNSs are known to fluctuate in popularity. Conclusions, though vague in nature, must be examined alongside other supplemental materials.

The research pertaining to various accessibility legislations around the world is limited, as it explores only a handful, while primarily focusing on the North-American landscape. More in-depth analysis of disability legislation, in particular relating to digital accessibility and inclusive design, would help in drawing conclusions on the role of government in enforcement and promotion of the various legislations.

There are two contradicting schools of thought on the topic of Internet usage and well being. On the one hand there is significant academic research pointing to Internet usage and the correlated positive effects on well being, primarily through social participation and inclusion (Miller, 2008; Freddolino \& Blaschke, 2008). There are, however, studies that suggest quite the opposite; Internet usage alienates people from their existing social circles, while online gaming can lead to addictive behavioural patterns (Miller, 2008; Freddolino \& Blaschke, 2008). Researchers suggest that the 
superficial relationships found online replace meaningful relationships in the real world (Miller, 2008). Within this paper the prevalent point of view is that Internet usage has positive influence on its users. While both arguments are valid and well supported, the view of the author is that the pros of Internet usage will continue to outweigh the cons.

\subsection{Ethnographic Account of Halifax, NS Experience}

Soon after beginning work on AccessNow, my partner and I were looking for different ways to raise funding for the project. An opportunity came up in the form of a national business model competition, to be held in Halifax, Nova Scotia mid March. To qualify for the competition we had to prepare an eight-minute video describing the problem we are solving in the framework of the business model canvas (BMC); the canvas is a fairly recent tool used by entrepreneurs to identify various elements of the business idea, such as revenue streams, value proposition, channels, and others. We worked on the video for close to two weeks, breaking only so I can walk and feed my dog. Every day I ventured downtown to my colleague's home, and every night we video chatted and practiced the presentation. Finally, we had submitted our application, taking some time to step back and focus on other things for a short while. There was a very short window between the application submission date and the actual travel dates. At a certain point I began thinking "They cannot possibly leave so little time for everyone to make travel arrangements". I was particularly concerned with the extensive process of booking travel and accommodations for a person in a wheelchair. Being a trained

pessimist I had convinced myself that we did not make it, only to be pleasantly surprised a couple of days later with a congratulatory e-mail. 
We were very excited. There was a trip allowance, meaning most expenses will be covered, and neither of us have ever been to Halifax before. With less than ten days before we had to present to a panel of judges at Dalhousie University, we had to not only make all arrangements, but also polish the presentation to perfection. We practiced and presented to Ryerson faculty, worked and reworked the slides and verbiage of presentation countless times, and merely drove ourselves to a point of exhaustion. All other responsibilities were put on hold; school, work, and family were background distractions. Every detail of the presentation was calculated, from images used to placement of text, to where we would stand in the room. Reflecting back on the experience, there are very few ventures I have worked on as hard as I did on this specific presentation. We were driven by the ideology of the venture as much as by the prospect of receiving prize money.

As we began making our travel arrangements I learned the difference between booking accommodations for an ambulatory individual, such as myself, and booking the same itinerary for an individual using a wheelchair. Firstly, my colleague uses a motorized chair, which is much heavier, more complex, and thus more expensive. Based on past experiences, where the chair was mistreated and broken by airline employees, my colleague refused to travel with her existing chair. Our program director, as well as the competition organizers urged her to find out whether it is possible to rent a motorized chair upon arrival in Halifax. Days of research and back and forth, led us to a local service that rents chairs on a monthly basis. Though we only required the chair for four days, the full monthly amount of $\$ 500$ had to be paid out in advance. The competition organizers generously offered to cover the cost, accompanied by a sigh of relief on our side. In addition, my colleague would normally travel with a caretaker, and considering 
the massive time constraints we were working under, finding someone on such short notice was no easy feat. I listened as my colleague phoned the hotel and discussed the accessibility features available in the rooms, eventually securing a room for herself. We had to take separate flights, leaving from different airports, simply based on price and convenience. While I was able to fly out from the Billy Bishop airport in Downtown Toronto, my colleague was forced to book flights that were close to $60 \%$ more expensive, as the accessibility features at Pearson airport are better suited for her needs. I was feeling overwhelmed simply listening to my colleague list everything that had to be done in advance, and I was not even the one requiring special assistance.

Conducting research online on the level of accessibility of a city can be extremely time-consuming, and the literature is often outdated and misinformed. My colleague decided to connect with a resident Haligonian who uses a wheelchair. We connected with a local photographer who is a vocal activist on all accessible matters. His input was very valuable, from accessible dining recommendations to accessible taxi services (there was a total of ten accessible taxi vans in Halifax, at the time of visit). We met with this individual for a traditional lobster dinner on the harbourfront on our second night in Halifax. I listened to stories about the terrible road conditions in Halifax, and the lack of municipal intervention in the efforts to keep the streets safe and accessible. It was not until the next morning, the actual competition day that I got to experience the icy Halifax streets.

Prior to the presentation day, a particularly frustrating experience took place. The limited number of accessible taxis in Halifax, and the worsening weather conditions, alerted us to the fact that perhaps we should order a taxi ahead of time, ensuring we get 
to the university campus in time for the big day. I decided to order the taxis myself, hoping to alleviate some of the planning stress off my colleague's shoulders. I called the first company and asked to order an accessible taxi for the next morning. I was told by the operator 'I cannot guarantee a van, as we do not know if the drivers will be on the road, or busy with another customer'. I explained the importance of us being at the university campus, and that we need the guarantee as we cannot venture by foot, and chair, due to freezing weather conditions. Nothing could be done, 'Call back 20 minutes before you need the van tomorrow, we will know better'. I phoned the second taxi company in the city, and received the same answer. The next morning I called again, the first company still refused to guarantee a ride, while the second said they will send someone. I began feeling an overwhelming sense of helplessness and stress; both because of the impending presentation, and the prospect of not being able to get to the campus in time. Once we came down to the hotel lobby to wait for our taxi, we noticed both companies have sent cars. We went into the vehicle that got there first. While my colleague was getting strapped in the back of the vehicle, I was swarmed by five other taxi drivers waiting at the hotel for business; in an accusatory tone they kept repeating, 'Why would you call two cars?'. I tried to defend my actions by pointing the fingers back at their employer, 'They would not guarantee a car, and I needed to make sure we will be at the university on time, what else was I supposed to do?'. I felt attacked, shamed and mostly frustrated. My propensity to plan ahead seemed to have backfired and turned me into a non-caring, obnoxious city dweller.

Determined to do our best in the competition, we presented in the first round, and felt great about our performance. Eager to learn whether we moved to the next stage we waited patiently around campus. Soon after we found out we were not one of the finalist 
teams. We wanted to leave the premises immediately, but decided to stick around in hopes of getting valuable feedback from the judges. Shortly thereafter we decided to leave, and head over to the shopping area, only a few minutes away. I should mention the roads were entirely iced over, and the conditions were only getting worse, in preparation for a large snow storm that was to hit Halifax later that night. Temperatures were 25 below zero, on average, with strong wind currents coming in from the oceanfront. Travelling by foot, and chair, on these icy roads proved close to impossible. The snow banks piled at the edge of sidewalks have frozen into solid three feet high ice blocks, making it impossible to cross the road in any direction. I was genuinely concerned for my own well being, as I know myself to be somewhat of a klutz. This journey was a much more complicated trip for my colleague, trying to navigate a foreign chair in an entirely inaccessible city. The frustration of trying to cross the street in an unwelcoming city, coupled with the all too recent competition loss, made for a very gloomy afternoon. We have worked ourselves to exhaustion in the weeks leading up to the competition, and we could not even relax in the comfort of our own home.

At this point I was happy the event was over, and sort of relieved we no longer had to keep face. I was tired and bitter. The after-party for the competition was held at a historic bar on the university campus. Prior to the event commencing we discovered we will not be attending as the building was entirely inaccessible. I could not stop myself from thinking 'would we have moved on to the finals if my colleague was not in a chair? They cannot possibly have a winning team that is unable to celebrate at the after party'. I quickly dismissed the thought, as I understood that I would never find out the real answer, nor was I interested in playing politics. We headed back to the hotel, looking forward to our flights home the next morning. When we woke up, we were horrified to 
find four feet of snow piled on every street and corner of the city. Restaurants were closed, and the city seemed eerily deserted. We were grounded for at least another night, and it seemed we will never get home.

Eventually we escaped the frozen perils of Halifax and safely arrived at home. Upon arrival I recall looking at my city through rose-coloured lenses. I appreciated every ramp, every automated door, and every salt covered inch of my city's sidewalk. This hypersensitivity however, also brought my attention to details I never noticed before. I found myself analyzing every elevator and front door button, 'This button is too far from the door, it will close by the time you get back!'. Selfishly, I placed myself in the shoes of my colleague, under different circumstances. 'How am I supposed to get inside this establishment, if I had a stroller?'. Accessibility is not only an issue of the disabled, it is a matter that will touch all of us at one point in our lives, to a lesser or greater degree. I want to be a part of an inclusive society that considers accessibility a necessary element of design, and not simply an afterthought.

\section{$\underline{10.0}$ Discussion}

The research presented in this paper illustrates the economic, social, and legislative forces that currently drive the market of accessible digital media products and services. While it has been demonstrated the market segment of individuals with disabilities is vastly underrepresented in these markets, a shift towards more inclusive design is beginning to take place. Recent Canadian census data, presented in Figure 2.0 below, illustrates that people with disabilities, above the age of 15 , are over two times as likely to not have any employment income, when compared to people without disabilities 
of the same age group (Statistics Canada, 2012). As seen in Figure 2.0 below, only about $20.6 \%$ of individuals with disabilities in Canada earn above the national average of $\$ 49,000$, compared with $30.2 \%$ of people without disabilities (Statistics Canada, 2012; Statistics Canada, 2014). These figures may appear insignificant, however when compared to the entire Canadian population of individuals aged 15 and over, these numbers gain more meaning. Individuals with disabilities earning above the national average comprises about $1.22 \%$ of the Canadian population, while people without disabilities earning the same figures makes up about $20 \%$ of the Canadian population (Statistics Canada, 2012; Statistics Canada, 2014).

Evidently there is a significant employment income gap between people with disabilities and people without disabilities. Lower income, in combination with increased healthcare costs for individuals with disabilities, paint a bleak, though not hopeless, picture. According to Figure 2.0 below, over 650,000 individuals with disabilities living in Canada have employment income above $\$ 30,000$ allowing for significant disposable income spending (Statistics Canada, 2012). Catering to the disabled population market segment has great potential earnings for companies providing digital services and products. This figure is greatly enhanced when taking into account the disabled populations in the United States and the rest of the world. In addition, efforts such as creating a more inclusive web, and investment in further development of assistive technologies would provide individuals with disabilities greater access to resources, which in turn can lead to more meaningful employment opportunities.

The ethnographic accounts of my experiences working on AccessNow, peppered in various sections of this paper, help define the concepts in a contextual framework. 
Throughout different stages of the project, answers to questions pertaining to market size and existing accessibility legislature, helped shape the service as it stands today. The more I delved into the research, the better understanding I had of both the market segments we aim to serve, as well as necessity and efficacy of the service. Having had the opportunity to interact with AccessNow users, the outpour of support and positive feedback displayed have been a great indicator of the thirst and room for more accessibility-focused digital services and products. Individuals with disabilities have the means and want to spend money, and we are only but fulfilling a small portion of an otherwise large gap in the market.

\subsection{Conclusion}

The web has been presented as a disembodied space allowing individuals with disabilities to distance themselves from their impairments (Bundon \& Clarke, 2014). While this statement may hold true, it is becoming more evident that with the introduction of web 2.0 and the shift in emphasis on user-generated content, individuals with disabilities are finding an outlet in various online forums (Miller, 2008; Blom et al., 2014; Shpigelman \& Gill, 2014; Bundon \& Clarke, 2015). They are able to seek out relevant information and connect with others who may experience similar impairments, beyond the confinements of their immediate physical environment. This realization supports the movement to eradicate the use of the medical model when referring to individuals with disabilities, and acknowledge their abilities within the context of the social model. 
Figure 2.0

Employment income for adults with and without disabilities, Canada, provinces and territories, occasional, 2012

\begin{tabular}{|c|c|c|c|}
\hline Employment income & Disability & Statistics & 2012 \\
\hline \multirow{6}{*}{$\begin{array}{l}\text { Total population, } 15 \\
\text { years and over }\end{array}$} & \multirow{2}{*}{ Total population } & Number of persons & $27,516,200$ \\
\hline & & Percentage & 100 \\
\hline & \multirow{2}{*}{$\begin{array}{l}\text { Persons with } \\
\text { disabilities }\end{array}$} & Number of persons & $3,775,910$ \\
\hline & & Percentage & 100 \\
\hline & \multirow{2}{*}{$\begin{array}{l}\text { Persons without } \\
\text { disabilities }\end{array}$} & Number of persons & $23,740,290$ \\
\hline & & Percentage & 100 \\
\hline \multirow{6}{*}{$\begin{array}{l}\text { Without employment } \\
\text { income }\end{array}$} & \multirow{2}{*}{ Total population } & Number of persons & $8,174,290$ \\
\hline & & Percentage & 29.7 \\
\hline & \multirow{2}{*}{$\begin{array}{l}\text { Persons with } \\
\text { disabilities }\end{array}$} & Number of persons & $2,147,540$ \\
\hline & & Percentage & 56.9 \\
\hline & \multirow{2}{*}{$\begin{array}{l}\text { Persons without } \\
\text { disabilities }\end{array}$} & Number of persons & $6,026,750$ \\
\hline & & Percentage & 25.4 \\
\hline \multirow{6}{*}{$\begin{array}{l}\text { With employment } \\
\text { income }\end{array}$} & \multirow{2}{*}{ Total population } & Number of persons & $19,341,420$ \\
\hline & & Percentage & 70.3 \\
\hline & \multirow{2}{*}{$\begin{array}{l}\text { Persons with } \\
\text { disabilities }\end{array}$} & Number of persons & $1,627,890$ \\
\hline & & Percentage & 43.1 \\
\hline & \multirow{2}{*}{$\begin{array}{l}\text { Persons without } \\
\text { disabilities }\end{array}$} & Number of persons & $17,713,540$ \\
\hline & & Percentage & 74.6 \\
\hline \multirow{6}{*}{ Under $\$ 5,000$} & \multirow{2}{*}{ Total population } & Number of persons & $2,578,940$ \\
\hline & & Percentage & 13.3 \\
\hline & \multirow{2}{*}{$\begin{array}{l}\text { Persons with } \\
\text { disabilities }\end{array}$} & Number of persons & 388,780 \\
\hline & & Percentage & 23.9 \\
\hline & \multirow{2}{*}{$\begin{array}{l}\text { Persons without } \\
\text { disabilities }\end{array}$} & Number of persons & $2,190,160$ \\
\hline & & Percentage & 12.4 \\
\hline \multirow{6}{*}{$\$ 5,000$ to $\$ 9,999$} & \multirow{2}{*}{ Total population } & Number of persons & $1,593,950$ \\
\hline & & Percentage & 8.2 \\
\hline & \multirow{2}{*}{$\begin{array}{l}\text { Persons with } \\
\text { disabilities }\end{array}$} & Number of persons & 154,680 \\
\hline & & Percentage & 9.5 \\
\hline & \multirow{2}{*}{$\begin{array}{l}\text { Persons without } \\
\text { disabilities }\end{array}$} & Number of persons & $1,439,270$ \\
\hline & & Percentage & 8.1 \\
\hline \multirow{6}{*}{$\$ 10,000$ to $\$ 14,999$} & \multirow{2}{*}{ Total population } & Number of persons & $1,480,380$ \\
\hline & & Percentage & 7.7 \\
\hline & \multirow{2}{*}{$\begin{array}{l}\text { Persons with } \\
\text { disabilities }\end{array}$} & Number of persons & 122,250 \\
\hline & & Percentage & 7.5 \\
\hline & \multirow{2}{*}{$\begin{array}{l}\text { Persons without } \\
\text { disabilities }\end{array}$} & Number of persons & $1,358,130$ \\
\hline & & Percentage & 7.7 \\
\hline
\end{tabular}




\begin{tabular}{|c|c|c|c|}
\hline \multirow{6}{*}{$\$ 15,000$ to $\$ 19,999$} & \multirow{2}{*}{ Total population } & Number of persons & $1,231,240$ \\
\hline & & Percentage & 6.4 \\
\hline & \multirow{2}{*}{$\begin{array}{l}\text { Persons with } \\
\text { disabilities }\end{array}$} & Number of persons & 103,310 \\
\hline & & Percentage & 6.3 \\
\hline & \multirow{2}{*}{$\begin{array}{l}\text { Persons without } \\
\text { disabilities }\end{array}$} & Number of persons & $1,127,930$ \\
\hline & & Percentage & 6.4 \\
\hline \multirow{6}{*}{$\$ 20,000$ to $\$ 29,999$} & \multirow{2}{*}{ Total population } & Number of persons & $2,302,690$ \\
\hline & & Percentage & 11.9 \\
\hline & \multirow{2}{*}{$\begin{array}{l}\text { Persons with } \\
\text { disabilities }\end{array}$} & Number of persons & 207,300 \\
\hline & & Percentage & 12.7 \\
\hline & \multirow{2}{*}{$\begin{array}{l}\text { Persons without } \\
\text { disabilities }\end{array}$} & Number of persons & $2,095,390$ \\
\hline & & Percentage & 11.8 \\
\hline \multirow{6}{*}{$\$ 30,000$ to $\$ 39,999$} & \multirow{2}{*}{ Total population } & Number of persons & $2,307,890$ \\
\hline & & Percentage & 11.9 \\
\hline & \multirow{2}{*}{$\begin{array}{l}\text { Persons with } \\
\text { disabilities }\end{array}$} & Number of persons & 166,700 \\
\hline & & Percentage & 10.2 \\
\hline & \multirow{2}{*}{$\begin{array}{l}\text { Persons without } \\
\text { disabilities }\end{array}$} & Number of persons & $2,141,190$ \\
\hline & & Percentage & 12.1 \\
\hline \multirow{6}{*}{$\$ 40,000$ to $\$ 49,999$} & \multirow{2}{*}{ Total population } & Number of persons & $2,006,300$ \\
\hline & & Percentage & 10.4 \\
\hline & \multirow{2}{*}{$\begin{array}{l}\text { Persons with } \\
\text { disabilities }\end{array}$} & Number of persons & 149,630 \\
\hline & & Percentage & 9.2 \\
\hline & \multirow{2}{*}{$\begin{array}{l}\text { Persons without } \\
\text { disabilities }\end{array}$} & Number of persons & $1,856,670$ \\
\hline & & Percentage & 10.5 \\
\hline \multirow{6}{*}{$\$ 50,000$ to $\$ 59,999$} & \multirow{2}{*}{ Total population } & Number of persons & $1,490,030$ \\
\hline & & Percentage & 7.7 \\
\hline & \multirow{2}{*}{$\begin{array}{l}\text { Persons with } \\
\text { disabilities }\end{array}$} & Number of persons & 99,770 \\
\hline & & Percentage & 6.1 \\
\hline & \multirow{2}{*}{$\begin{array}{l}\text { Persons without } \\
\text { disabilities }\end{array}$} & Number of persons & $1,390,260$ \\
\hline & & Percentage & 7.8 \\
\hline \multirow{6}{*}{$\$ 60,000$ or more } & \multirow{2}{*}{ Total population } & Number of persons & $4,350,000$ \\
\hline & & Percentage & 22.5 \\
\hline & \multirow{2}{*}{$\begin{array}{l}\text { Persons with } \\
\text { disabilities }\end{array}$} & Number of persons & 235,460 \\
\hline & & Percentage & 14.5 \\
\hline & \multirow{2}{*}{$\begin{array}{l}\text { Persons without } \\
\text { disabilities }\end{array}$} & Number of persons & $4,114,540$ \\
\hline & & Percentage & 23.2 \\
\hline
\end{tabular}

\section{Source}

Statistics Canada. 
People with disabilities are becoming increasingly more active online, especially in the social media sphere, bringing attention to the accessibility barriers these sites posses. Efforts such as the WCAG 1.0 and 2.0 have attempted, and in some instances successfully helped, in lifting said barriers (Kelly et al., 2009a). Evidence, however, shows that the majority of public websites are not accessible (Kelly et al., 2005; Ribera et al., 2009; Easton, 2011; Hanson \& Richards, 2013). Some contributing factors include lack of resources, training or understanding of the market, such as size, needs, and potential (Loiacono \& Djamasbi, 2013).

It is clear that in order for accessibility to become an integrated part of web design, many more factors will need to come together to make it a reality. Several studies suggest that governmental intervention can aid the process by putting pressure on the relevant parties (Easton, 2011; Hanson \& Richards, 2013; Garber, 2013; Ribera et al., 2009). In addition, an education program to help businesses understand the economic benefits associated with accessible design may help eradicate the notion that people with disabilities are an inefficient market segment. The gap in universal design that currently exists in the digital media market is an attractive and relevant economic and social opportunity for positive change.

At some point, every person will become disabled in some way, whether it is temporary or prolonged. Working towards and advocating for a universal web now, will help further a knowledge-based economy in the future (Harper \& Yesilada, 2008). As the baby-boomer population continues to age, the number of people with disabilities will rise significantly. In Ontario alone, currently one in seven individuals is living with a 
disability, or 1.85 million individuals (Ontario Ministry of Economic Development, Employment \& Infrastructure, 2014). This number is projected to increase to one in five by 2036 , accounting for $40 \%$ of income in Ontario, or approximately $\$ 536$ billion (Ontario Ministry of Economic Development, Employment \& Infrastructure, 2014). Catering to the disabled population provides an organization an opportunity to not only position itself favourably in the social context, but also an opportunity to increase market share and profits.

Working on AccessNow has shown me that there is an appetite for accessible digital media products and services, however the understanding of what inclusive design may entail is limited, at best. Prior to embarking on this venture, my knowledge of digital accessibility was minimal, for I never had to consider it within the context of my own life. I consider this learning experience to have been immensely enriching, and the start of a lifelong journey on a path to better understand accessibility and the ways in which it affects all people.

It is evident that there is a need for advanced development of existing accessibility guidelines. Further research into market size and need will help determine the type of monetary, legislative and social support that is required to create a fully inclusive web and other accessible digital media products and services. Accessibility and inclusivity must be incorporated into design practices from the start, as opposed to as an afterthought. A shift in defining whom accessible design serves can lead to immense change, for we are designing for our future selves. The social and economic benefits to inclusive design are undeniable, and can help advance positive change in a market segment that has been long ignored. 


\section{Reference List}

Abbott, C. (2007). Defining Assistive Technologies - a Discussion. Journal of Assistive Technologies, 1(1), 6-9. DOI:http://dx.doi.org/10.1108/17549450200700002

Ahmad, M., \& Ahmad, M. M. (2011). Measuring Support Provisions for People Living with Disabilities in South Asia: An Accessibility Index. Journal of Social Service Research, 37(4), 439-455. DOI:10.1080/01488376.2011.578034

Anastasiou, D., \& Kauffman, J. M. (2013). The Social Model of Disability: Dichotomy between Impairment and Disability. Journal of Medicine and Philosophy, 38(4), 441459. DOI:10.1093/jmp/jht026

Blom, H., Marschark, M., Vervloed, M. P. J., \& Knoors, H. (2014). Finding Friends Online: Online Activities by Deaf Students and their Well-Being. PLoS One, 9(2), e88351. DOI:http://dx.doi.org/10.1371/journal.pone.0088351

Bundon, A., \& Hurd Clarke, L. (2015). Unless You Go Online You Are on Your Own: Blogging as a Bridge in Para-Sport. Disability \& Society, 30(2), 185-198. DOI:10.1080/09687599.2014.973477

Carr, D. (2010). Constructing Disability in Online Worlds: Conceptualizing Disability in Online Research. London Review of Education, 8(1), 51-61. DOI:10.1080/14748460903557738

Connor, D. J., \& Ferri, B. A. (2013). Historicising Dis/Ability: Creating Normalcy, Containing Difference. In M. Wappett \& K. Arndt (Eds.), Foundations of Disability Studies (pp. 29-68). New York, NY: Palgrave Macmillan.

Cox, J. (2012). Pregnancy as "Disability" and the Amended Americans with Disabilities Act. Boston College Law Review, 53(2), 443-487. Retrieved from http://ezproxy.lib.ryerson.ca/login?url=http://search.proquest.com/docview/160933123 4 ? accountid=13631

Crawford, G., Gosling, K. V., \& Light, B. (2011). The Social and Cultural Significance of Online Games. In G. Crawford et al. (Eds.), Online Gaming in Context (pp. 3-21). New York, NY: Routledge.

Cumming, T. M., Strnadová, I., Knox, M., \& Parmenter, T. (2014). Mobile Technology in Inclusive Research: Tools of Empowerment. Disability \& Society, 29(7), 999-1012. DOI:10.1080/09687599.2014.886556

Davidson, M. (2006). Universal Design: The Work of Disability in an Age of Globalization. In L. J. Davis (Ed.), The Disability Studies Reader (pp. 117-128). New York, NY: Routledge. 
Davis, L. J. (2013). Constructing Normalcy. In L. J. Davis (Ed.), The Disability Studies Reader (pp. 3-19). New York, NY: Routledge.

Easton, C. (2011). The Web Content Accessibility Guidelines 2.0: An Analysis of Industry Self-Regulation. International Journal of Law and Information Technology, 19(1), 7493. DOI:10.1093/ijlit/eaq015

Easton, C. (2013). An Examination of the Internet's Development as a Disabling Environment in the Context of the Social Model of Disability and Anti-Discrimination Legislation in the UK and USA. Universal Access in the Information Society, 12(1), 105-114. DOI:10.1007/s10209-011-0268-2

Ellis,K., \& Kent, M. (2011). Disability and New Media. New York: Routledge.

Ferri, D., \& Giannoumis, G. A. (2014). A Revaluation of the Cultural Dimension of Disability Policy in the European Union: The Impact of Digitization and Web Accessibility. Behavioral Sciences \& the Law, 32(1), 33-51. DOI:10.1002/bsl.2102

Flaherty, M., \& Roussy, A. (2014). A Failed Game Changer: Post-Secondary Education and the Accessibility for Ontarians with Disabilities Act. Education Law Journal, 24(1), 123. Retrieved from http://ezproxy.lib.ryerson.ca/login?url=http://search.proquest.com/docview/164214786 8 ? accountid $=13631$

Freddolino, P. P., \& Blaschke, C. M. (2008). Therapeutic Applications of Online Gaming. Journal of Technology in Human Services, 26(2-4), 423-446. DOI:10.1080/15228830802099998

Gallagher, D. J., Connor, D. J., \& Ferri, B. A. (2014). Beyond the Far too Incessant Schism: Special Education and the Social Model of Disability. International Journal of Inclusive Education, 18(11), 1120-1142. DOI:10.1080/13603116.2013.875599

Garber, L. (2013). Game accessibility: Enabling everyone to play. Computer, 46(6), 14-18. DOI:10.1109/MC.2013.206

Goering, S. (2015). Rethinking Disability: The Social Model of Disability and Chronic Disease. Current Reviews in Musculoskeletal Medicine, 8(2), 134-138. DOI: $10.1007 / \mathrm{s} 12178-015-9273-\mathrm{z}$

Hakobyan, L., Lumsden, J., O’Sullivan, D., \& Bartlett, H. (2013). Mobile Assistive Technologies for the Visually Impaired. Survey of Ophthalmology, 58(6), 513-528. DOI:10.1016/j.survophthal.2012.10.004 
Hanson. V., \& Richards, J. (2013). Progress on Web Accessibility? ACM Transactions on the Web, 7(1), Article No. 2 (30 pages). DOI: 10.1145/2435215.2435217

Harper, S., \& Yesilada, Y. (2008). Web Accessibility: A Foundation for Research. London: Springer.

Hoppestad, B. S. (2007). Inadequacies in Computer Access Using Assistive Technology Devices in Profoundly Disabled Individuals: An Overview of the Current Literature. Disability \& Rehabilitation: Assistive Technology, 2(4), 189-199. DOI:10.1080/17483100701249540

Karger, H., \& Rose, S. R. (2010). Revisiting the Americans with Disabilities Act after Two Decades. Journal of Social Work in Disability \& Rehabilitation, 9(2-3), 73-86. DOI:10.1080/1536710X.2010.493468

Kelly, B., Sloan, D., Phipps, L., Petrie, H., \& Hamilton, F. (2005). Forcing Standardization or Accommodating Diversity? A Framework for Applying the WCAG in the Real World. Proceedings of the 2005 International Cross-Disciplinary Workshop on Web Accessibility (W4A), pp. 46-54. New York: ACM Press. Retrieved from http://citeseerx.ist.psu.edu/viewdoc/download?doi=10.1.1.59.8056\&rep=rep1\&type=pd f

Kelly, B., Sloan, D., Brown, S., Seale, J., Lauke, P., Ball, S., \& Smith, S. (2009a). Accessibility 2.0: Next Steps for Web Accessibility. Journal of Access Services, 6:1-2, 265-294. DOI: 10.1080/15367960802301028

Kelly, B., Nevile, L., Sloan, D., Fanou, S., Ellison, R., \& Herrod, L. (2009b). From Web Accessibility to Web Adaptability. Disability and Rehabilitation: Assistive Technology, 4(4), 212-226. DOI:10.1080/17483100902903408

Koutsogeorgou, E., Leonardi, M., Bickenbach, J. E., Cerniauskaite, M., Quintas, R., \& Raggi, A. (2014). Social Capital, Disability, and Usefulness of the International Classification of Functioning, Disability and Health for the Development and Monitoring of Policy Interventions. Disability \& Society, 29(7), 1104-1116.

DOI:10.1080/09687599.2014.910106

Lewthwaite, S. (2014). Web Accessibility Standards and Disability: Developing Critical Perspectives on Accessibility. Disability and Rehabilitation, 36(16), 1375-1383. DOI: 10.3109/09638288.2014.938178

Loiacono, E., \& Djamasbi, S. (2013). Corporate Website Accessibility: Does Legislation Matter? Universal Access in the Information Society, 12(1), 115-124.

DOI:10.1007/s10209-011-0269-1 
Mahmud, J., \& Ramakrishnan, I. (2012). Transaction Models for Web Accessibility. World Wide Web, 15(4), 383-408. DOI:10.1007/s11280-011-0135-3

McClimens, A., \& Hyde, M. (2012). Intellectual Disability, Consumerism and Identity: To Have and Have Not? Journal of Intellectual Disabilities, 16(2), 135-144.

DOI:10.1177/1744629512445844

McColl, M. A., Schaub, M., Sampson, L., \& Hong, K. (March 2010). A Canadians with Disabilities Act? Retrieved from http://www.disabilitypolicyalliance.ca/federal_policy_team/federal_canadianswithdisab ilitiesact/canadians-with-disabilities-act.html

Micheletti, M., \& Stolle, D. (2008). Fashioning Social Justice through Political Consumerism, Capitalism, and the Internet. Cultural Studies, 22(5), 749-769. DOI:10.1080/09502380802246009

Migone, A. (2007). Hedonistic Consumerism: Patterns of Consumption in Contemporary Capitalism. Review of Radical Political Economics, 39(2), 173-200. DOI:10.1177/0486613407302482

Miller, S. (2008). The Effect of Frequency and Type of Internet Use on Perceived Social Support and Sense of Well-Being in Individuals with Spinal Cord Injury. Rehabilitation Counseling Bulletin, 51(3), 148-158. DOI:10.1177/0034355207311315

Monsebraaten, L. (2015a, February 13). Ontario Needs to Boost Accessibility Efforts. The Toronto Star. Retrieved from http://www.thestar.com/news/queenspark/2015/02/13/ontario-needs-to-boostaccessibility-efforts.html

Monsebraaten, L. (2015b, February 24). Ontario to Reduce Enforcement of Accessibility Law. The Toronto Star. Retrieved from http://www.thestar.com/news/canada/2015/02/24/ontario-to-reduce-enforcement-ofaccessibility-law.html

Ontario Ministry of Economic Development, Employment \& Infrastructure. (2014). Why Accessibility is Good for Ontario (Infographic). Retrieved from http://www.mcss.gov.on.ca/en/mcss/programs/accessibility/understanding_accessibility /

Plura, M. (2014, November 28). EU Must Stop Discrimination Against Disabled Persons. The Parliament Magazine. Retrieved from https://www.theparliamentmagazine.eu/articles/opinion/eu-must-stop-discriminationagainst-disabled-persons 
Priestley, M., \& Lawson, A. (2015). Mapping Disability Policies in Europe: Introducing the Disability Online Tool of the Commission (DOTCOM). Alter - European Journal of Disability Research, Revue Europeen De Recherche Sur Le Handicap, 9(1), 75-78. DOI:10.1016/j.alter.2014.12.006

Ribera, M., Porras, M., Boldu, M., Termens, M., \& Sule, A. (2009). Web Content Accessibility Guidelines 2.0: A Further Step Towards Accessible Digital Information. Emerald Insight, 43(4), 392-406.

Ross, T. (2013). Advancing Ontario's Accessibility: A Study of Linguistic, Discursive, and Conceptual Barriers. Canadian Journal of Urban Research, 22(1), 126-144. Retrieved from http://ezproxy.lib.ryerson.ca/login?url=http://search.proquest.com/docview/144370995 2 ?accountid=13631

Rothman, J. C. (2010). The Challenge of Disability and Access: Reconceptualizing the Role of the Medical Model. Journal of Social Work in Disability \& Rehabilitation, 9(2-3), 194-222. DOI:10.1080/1536710X.2010.493488

Rush, C. (2012). Amending the Americans with Disabilities Act: Shifting Equal Employment Opportunity Obligations in Public Human Resource Management. Review of Public Personnel Administration, 32(1), 75-86. DOI:10.1177/0734371X11433883

Schaffhauser, D. (2013). Assistive Tech Goes Mainstream. The Education Digest, 79(4), 5156. Retrieved from http://ezproxy.lib.ryerson.ca/login?url=http://search.proquest.com/docview/146461908 2 ?accountid=13631

Shpigelman, C., \& Gill, C. J. (2014). How do Adults with Intellectual Disabilities Use Facebook? Disability \& Society, 29(10), 1601-1616.

DOI:10.1080/09687599.2014.966186

Song, F. W. (2010). Theorizing Web 2.0. Information, Communication \& Society, 13(2), 249 275. DOI:10.1080/13691180902914610

Statistics Canada. (2012). Total Income for Adults with and without Disabilities, by Age Group and Sex, Canada, Provinces and Territories (Data File). Retrieved from http://www5.statcan.gc.ca/cansim/a26?lang=eng\&retrLang=eng\&id=1150014\&paSer= $\&$ pattern $=\&$ stByVal $=1 \& p 1=1 \& p 2=35 \&$ tabMode $=$ dataTable $\&$ csid $=$

Statistics Canada. (2014). Earnings, Average Weekly, by Province and Territory (Date File). Retrieved from http://www.statcan.gc.ca/tables-tableaux/sum-som/101/cst01/labr79eng.htm

Sum, S., Mathews, M. R., Pourghasem, M., \& Hughes, I. (2008). Internet Technology and Social Capital: How the Internet Affects Seniors' Social Capital and 
Wellbeing. Journal of Computer-Mediated Communication, 14(1), 202-220.

DOI:10.1111/j.1083-6101.2008.01437.x

The Canadian Press, (2015, June 3). Ontario Announces Plan to Address Accessibility Issues. Canadian Broadcasting Corporation (CBC). Retrieved from http://www.cbc.ca/news/canada/toronto/ontario-announces-plan-to-addressaccessibility-issues-1.3099118

Tzavela, E. C., \& Mavromati, F. M. (2013). Online Social Networking in Adolescence: Associations with Development, Well-Being and Internet Addictive Behaviors. International Journal of Child and Adolescent Health, 6(4), 411-420. Retrieved from $\mathrm{http}$ //ezproxy.lib.ryerson.ca/login?url=http://search.proquest.com/docview/162551881 8 ?accountid $=13631$

Unites States Census Bureau. (2010). Computer and Internet Usage by Age and Disability Status (Data File). Retrieved from http://www.census.gov/people/disability/publications/sipp2010.html

Vanderheiden, G. C., (1995). Design of HTML (Mosaic) Pages to Increase their Accessibility to Users with Disabilities; Strategies for Today and Tomorrow. Retrieved from http://trace.wisc.edu/archive/html_guidelines/version1.html

World Health Organization. (2014). Disabilities and Rehabilitation. Geneva, Switzerland: Author. Retrieved from http://www.who.int/disabilities/en/

Yuan, B., Folmer, E., \& Harris, F. (2011). Game Accessibility: A Survey. Universal Access in the Information Society,10(1), 81-100. DOI:10.1007/s10209-010-0189-5

Zhuang, Y., Baldwin, J., Antunna, L., Yazir, Y. O., Ganti, S., \& Coady, Y. (2013). Tradeoffs in Cross Platform Solutions for Mobile Assistive Technology. 2013 IEEE Pacific Rim Conference on Communications, Computers and Signal Processing (PACRIM), 330335. DOI:10.1109/PACRIM.2013.6625498 